\title{
Relationships among Utilitarian and Hedonic Values, Brand Affect and Brand Trust in the Smartphone Industry
}

\author{
Dr. İkram Daştan \\ Department of Management, Faculty of Economics and Administrative Sciences \\ Yalova University, Turkey \\ E-mail: idastan@yalova.edu.tr \\ Dr. Fatih Geçti (corresponding author) \\ Department of Management, Faculty of Economics and Administrative Sciences \\ Yalova University, Turkey \\ E-mail: fgecti@yalova.edu.tr
}

Received: March 8, 2013 Accepted: March 21, 2014 Published: April 1, 2014

doi:10.5296/jmr.v6i2.5261

URL: http://dx.doi.org/10.5296/jmr.v6i2.5261

\begin{abstract}
The purpose of this study is to examine the relationships among utilitarian and hedonic values, brand affect and brand trust in the smart phone industry. In this regard, an online survey was conducted on smart phone consumers in Turkey. Online consumers participated in the survey which took place in the relevant web page. The hypotheses were tested using structural equation modeling. The findings indicate that utilitarian and hedonic values significantly influence brand affect, and brand affect has a significant impact on brand trust. While utilitarian value is positively related to brand trust, hedonic value is found to have no significant influence on brand trust.
\end{abstract}

Keywords: Utilitarian value, Hedonic value, Brand trust, brand affect, Smart phone industry 


\section{Introduction}

As is known, it is more advantageous for businesses to maintain their existing customers rather than acquiring the new ones. Businesses that are aware of this fact now intensely use the relationship marketing activities and further increase their investments in their current customers. One of the factors that constitute the basis of relationship marketing is trust in the brand. Trust has a crucial role not only in the establishment of long term relationships between the customer and the firm, but also has an effect on firms' creation of strong brands.

Brand trust is based on the consumer's belief that the brand has specific qualities that make it consistent, competent, honest and responsible (Jahangir et al, 2009). In branding literature, there are a great number of studies that discuss the concept of brand trust. The reason why researchers are very interested in brand trust is because it is a quite important concept for theorists and especially for the practitioners. According to the relevant literature, there are several variables that affect brand trust. In the present study, some of these variables such as value and brand affect are considered and the relationships between them are investigated.

Brand affect has a role in the relationship between the brand and customer as much as brand trust, and brand affect might have an impact on establishing this relationship (Kabaday1 \& Alan, 2012). The structure of brand trust comprises a very well-thought and designed process; however, brand affect incorporates mainly spontaneous, sudden, and less consideration (Chaudhuri \& Holbrook, 2001). One of the other important factors that forms the relationships between customers and brands is the value the brand provides for the customer. This is due to the fact that the foremost motivation to be the customer of a brand is the high value the brand provides (Yang \& Peterson, 2004). It is stated that the value perception of the customer increases the purchase requests and decreases the efforts to search for alternatives (Pura, 2005). In this respect, the concept of value is one the most important factors that might affect establishing trust in the brand. In the present study, the concept of value is discussed in a dimensional approach and the dimensions are utilitarian value and hedonic value. In general, utilitarian value has been considered to be driven by the desire to fill a basic need or to accomplish a functional task (Ryu et al, 2010), while hedonic value is primarily associated with pleasure, arousal, fantasies, feelings, and fun (Hopkinson \& Pujari, 1999).

The current research was conducted on smartphone customers. As a matter of fact that smartphones that has entered into the society in the recent years are technological products used for many various reasons to facilitate our lives and provide high quality communication. Almost everybody now prefers these products instead of the traditional mobile phones. The involvement of smartphones is also at a very high level. Furthermore, smartphones provide both utilitarian and hedonic values, and therefore they may offer key solutions satisfying the consumer's needs. These phones have become essential for today's consumers and especially for young consumers because of the value they provide.

Global vendors shipped a total of 1,004.2 million smartphones worldwide, up 38.4\% from the 725.3 million units in 2012. Additionally, smartphones accounted for 55.1\% of all mobile phone shipments in 2013, up from the $41.7 \%$ of all mobile phone shipments in 2012 (IDC, 2013). It is implied that the smartphone industry in Turkey is parallel to the worldwide 
market. Smartphones are among the growth drivers in the Turkish market. During Q4 2013, sales of telecommunications increased by 44\% compared with Q4 2012, driven by strong smartphone sales and sales in the telecommunications sector were 10.6 billion Turkish Lira in 2013 (GFK, 2013).

While the smartphone industry is growing at such a rate, the emotional linkages between the smartphones and their users are becoming stronger. Today's consumers have become highly dependent on smartphones to retrieve useful information by a simple browse and click to access their smartphones as it is with them when they commute, relax at home, travel overseas and so on (Ting et al, 2001, p. 194). Besides, smart phone consumers are using their mobile devices beyond personal communications goals and treat them as a way to access content and share information, giving rise to the potential for mobile phones to become a platform that companies can employ for brand communication, transactions completion, and relationship-building purposes (Gao et al., 2012, p. 213).

When choosing smartphones, users can foresee which product they may choose and under what concept, which product is more useful, reliable, and important for them. Because smartphone users consider maintaining personal information security in the applications they operate through these devices and aim to store and share their work files in a safe way. This demonstrates that trust for these products is very crucial. Smart phone manufacturers constantly apply new methods and tests in order to increase the customer trust and commitment to these products. Successful manufacturers may take a step further while the rest may become being left with a disappearing segment of the smartphone industry. In this case, users that are to purchase a smartphone, may demonstrate a tendency to prefer products that have achieved a certain maturity and brand value.

Since smartphones are relatively new products, they were not included in the past studies in which the relationships among the structures in the research model were tested. Thus, by choosing the smartphone in the context of this study, it is possible to observe the research area from the perspective of a different product and industry so that it provides new viewpoints regarding the subject and a modest contribution to the related literature. In this respect, the current study aims to examine the relationships among utilitarian value, hedonic value, brand affect, and brand trust in the smartphone industry.

\section{The Research Model}

Figure 1 presents the research model. 


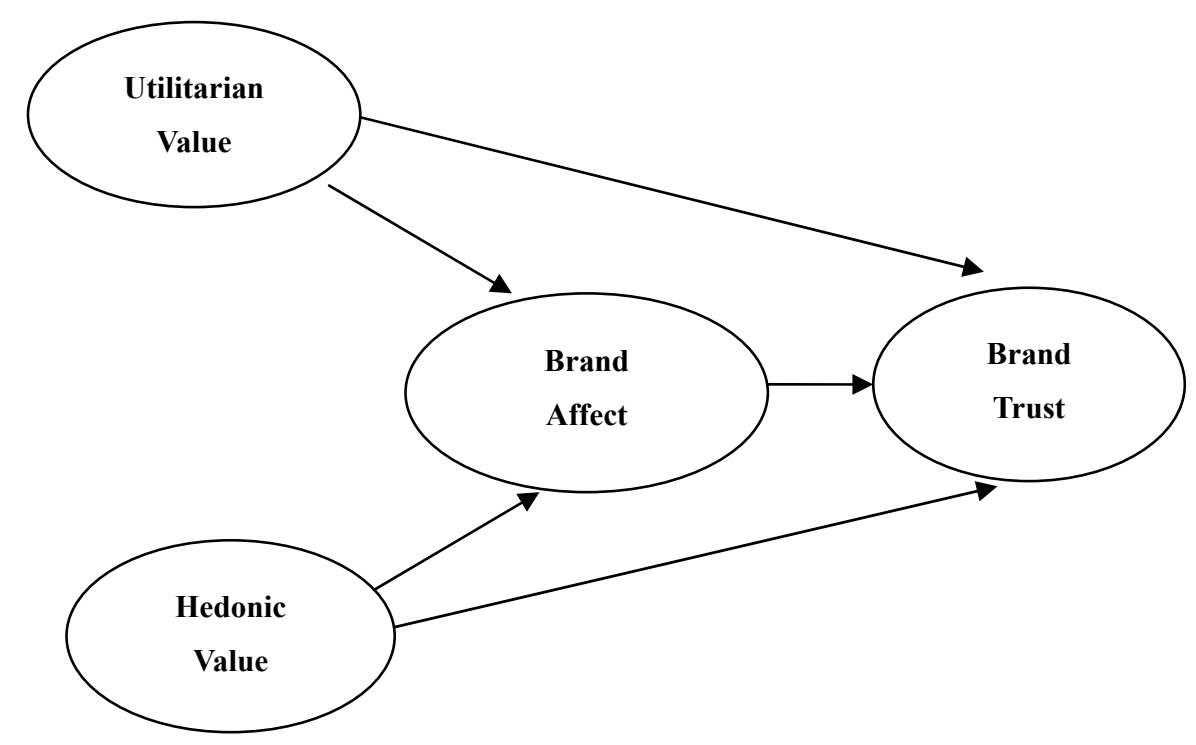

Figure 1. Research Model

\section{The Constucts within the Research Model and Research Hypotheses}

\subsection{Utilitarian Value and Hedonic Value}

Value is quite important and strategic concept for both consumers and marketers (Sweeney et al., 1997). Perceived value generally refers to the comparison between the utilities gained from purchases of goods and services and the prices paid for these utilities (Dodds \& Monroe, 1985; Zeithaml, 1988). Customer value is the customer evaluation regarding the product qualities, performance of product qualities, and the results of usage that provide convenience for the customer to obtain the product. Customer value is perceived by the customer instead of being objectively determined by the seller. These perceptions include the comparisons between the acquisitions of the customer and the renouncements he/she must make to gain these acquisitions (Woodruff, 1997).

Value is more individual and personal than quality, and it is a more preferential concept than quality. Even every kind of qualitative, quantitative, subjective, and objective factor that completes the shopping experience can be expressed as value (Zeithaml, 1988). Additionally, the definition about the value simply conceptualizes the perceived value as a tradeoff between quality and price, which is a subject of discussion. Accordingly, perceived value incorporates a more complex structure, and consumer preference is realized as a result of the dimensions of consumption value (Overby \& Lee, 2006).

According to the relevant literature, it is seen that these dimensions are utilitarian and hedonic values and it is understood that the perceived value is evaluated generally within the 
axis of these two dimensions (Hirschman \& Holbrook, 1982; Batra \& Ahtola, 1990; Babin et al, 1994; Hopkinson \& Pujari, 1999; Dhar \& Wertenbroch, 2000; Childers et al, 2001; Carpenter et al, 2005; Jones et al, 2006; Ryu et al, 2010). Utilitarian value is defined as a utilitarian outcome resulting from some type of conscious pursuit of an intended consequence (Babin et al, 1994, p. 645). Utilitarian value reflects more cognitive aspects of attitude and judgements of convenience and time saving (Overby \& Lee, 2006); thus, it is task-oriented and rational and evaluated as functional and instrumental in nature (Ryu et al, 2010). In contrast, hedonic value refers to consumers' multisensory images, fantasies and emotional arousal in using products (Hirschman \& Holbrook, 1982, p. 93). Hedonic value derived from pleasurable experince (Carpenter et al, 2005) and it is related more to spontaneous hedonic responses (Babin et al, 1994). Hedonic value represents the importance of the fun and enjoyment derived from the product/service or technology and has gained importance in technological environment; additionally, it has not only emotional aspects but it also include social aspects such as acceptance, recognition and influence needs (Pihlström, 2007, p. 6)

\subsection{Brand Affect}

The term 'affect' which is generally defined as a valenced feeling state (Erevelles, 1998, p.199) can be influential on consumer attitudes even in the absence of product beliefs (Taylor, 2004). Affect can also play an important role in consumer brand recall and recognition (Sung \& Kim, 2010). Brands are associated with some traits such as brand affect (Matzler et al, 2008) and these affective traits of a brand can serve as a primary basis of a brand's potential (Sung \& Kim, 2010). Brand affect is described as a brand's potential to elicit a positive emotional response in the average consumer as a result of its use (Chaudhuri \& Holbrook, 2001, p. 82).

\subsection{Brand Trust}

Trust is one of the most important factors in the development and success of a relationship between the parties. The term 'trust' is defined as a willingness to rely on an exchange partner in whom one has confidence (Moorman et al. 1992, p. 315) and exists when one party has confidence in an exchange partner's reliability and integrity (Morgan \& Hunt, 1994, p. 23). In branding literature, the concept of brand trust has been studied by many researchers (Ibanez et al., 2006; Gommans et al., 2001; Ha , 2004; Matzler et al, 2006a; Liu et al, 2011; Hanzaee \& Andervazh, 2012). In the current study, brand trust is defined as the willingness of the average consumer to rely on the ability of the brand to perform its stated functions (Chaudhuri \& Holbrook, 2001, p. 82).

\subsection{Value, Brand Affect and Brand Trust}

There are numerous studies in the literature that reveal the relationships among value, brand affect, and brand trust. In their study of customers who purchased books and airplane tickets via the internet, Harris \& Goode (2004) analyzed the role of trust in forming brand commitment by using service quality, perceived value, and customer satisfaction factors. A significant and positive relationship was found between perceived value and trust as a result of the first research conducted on those who purchased books on the internet. As a result of the second study conducted on those who purchased airplane tickets, a significant and 
positive relationship was found, as well. In this regard, it may be stated that value has a positive effect on trust.

Hanzaee \& Andervazh (2012) investigated the relationships between utilitarian and hedonic values and brand trust, and between brand trust and attitudinal and behavioral brand loyalty. The findings of their research revealed that utilitarian and hedonic values had a direct and positive effect on brand trust. According to the study by Ok et al. (2011) that attempted to explain the effect of perceived value on brand reliability and prestige, the effect of utilitarian value on brand trust was obtained via brand reliability and the effect of hedonic and social values on brand trust was maintained through brand prestige. There were indirect effects of utilitarian, hedonic, and social values on brand trust.

Matzler et al. (2006a) examined the moderator effect of some variables within the value-brand trust-brand loyalty chain. Accordingly, the strength of relationships of hedonic value and brand trust with brand trust and brand loyalty was affected by variables such as customer involvement, price consciousness, and brand consciousness. According to the findings, when price consciousness was low, hedonic value was more important in creating brand trust; however, when price consciousness was high, the effect of brand trust on attitudinal loyalty was much stronger. Furthermore, it was found that the effect of utilitarian value on brand trust was much lower for consumers with high brand consciousness.

Matzler et al. (2006b) analyzed the relationships between personality characteristics, hedonic value, brand affect, and brand loyalty. As a result of the study, they found that extroversion and openness of personality characteristics were significantly and positively related to the hedonic value. Openness directly influenced brand affect, while extroversion has indirectly impact on brand affect via hedonic value. It was revealed that extroverted customers perceived the hedonic value of a product much stronger.

Duman \& Mattila (2005) analyzed various emotional factors that could have an effect on value in their studies of cruise vacationers. In their study, the role of customer satisfaction in the affect-value relationship was also considered. According to the results, affective factors (hedonics, control, and novelty) were crucial determinants of the value created by the cruise trip. Hedonics was strongly related to the value perceptions and behavioral intentions of cruise vacationers. Customer satisfaction was the mediator variable in the relationship between affective factors and perceived value.

Chaudhuri \& Holbrook (2001) examined the role of brand loyalty in the relationship between brand trust, brand affect, and brand performance. According to their model, there was a chain effect from the value presented to the customer to the brand performance. A significant and positive relationship of hedonic value in the product class with the brand affect was also found. Anuwichhanont (2011) investigated the effect of price perception on customer loyalty in the airline industry. Primarily, the effect of the dimensions of perceived value on brand trust and brand affect, followed by how brand trust and brand affect played a role in customer loyalty were analyzed. Subsequently, regarding the low and high price perception groups, the moderator effect of price perception in the relationships between brand trust, brand affect, and loyalty was analyzed. Accordingly, price consciousness, as one of the price perception 
dimensions, had a strong moderator effect on brand trust, brand affect, and loyalty in the low price perception group. Kabadayı \& Alan (2012) tested the relationship between brand affect and brand trust, which had an impact on brand loyalty in a coffee shop. As a result, a positive relationship emerged between brand affect and brand trust. Similarly, in the study of Geçti \& Zengin (2013), which analyzed sports shoe consumers' attitudinal and behavioral brand loyalty and the relationship between brand affect and brand trust, it was revealed that there was a significant and positive relationship between brand trust and brand affect.

Based on the above discussion, the hypotheses are developed as follows;

H1: Utilitarian value will positively influence brand affect.

H2: Hedonic value will positively influence brand affect.

H3:Utilitarian value will positively influence brand trust.

H4: Hedonic value will positively influence brand trust.

H5: Brand affect value will positively influence brand trust.

\section{Methodology}

All of the smartphone consumers that live in Turkey constituted the population of the research. The research was limited with the sample because of restrictions such as time, cost, and difficulty in reaching all the population. Consumers who agreed to voluntarily participate in the online questionnaire established the sample framework. The online questionnaire form was available on the relevant webpage (docs.google.com) for approximately two months and every completed questionnaire was evaluated. Eventually, 633 consumers participated the survey.

The questionnaire contains two sections. In the first section, there are demographic features of the sample. In the second section, there are five-point Likert type (1=Strongly Disagree ... 5=Strongly Agree) scales used for testing the research model. Pihlström's (2007) scale was adapted to measure utilitarian and hedonic values. Brand affect and brand trust were measured by Chaudhuri \& Holbrook's (2001) scale. The proposed hypotheses were tested using structural equation modeling. SPSS and AMOS programs were used for data analysis.

\section{Results}

\subsection{Sample Profile}

Descriptive statistics for the sample showed that 60.8 percent of the participants were male, 76.8 percent were single, 83.9 percent were under 30 years old and 61.6 percent were university graduates. While 31.3 percent of the respondents were students, 29.2 percent were private sector employees. In addition, most of the participants (70.6 percent) were the consumers whose income level were under 2000 Turkish Lira.

\subsection{Measurement Model}

Anderson\&Gerbing's (1988) two-step approach was used before testing the research 
hypotheses. Therefore, the validity and reliability of the measurement model was firstly analyzed by conducting the confirmatory factor analysis. The hypotheses were then tested with the structural equation modeling. The exogenous structures in the measurement model were utilitarian and hedonic values and the endogenous structures were brand affect and brand trust. The goodness of fit statistics showed that the model provided an acceptable fit $($ Chi-square $(\chi 2)=277.063 ; \mathrm{Df}=70 ; \chi 2 / \mathrm{df}=3.96 ; \mathrm{GFI}=0.94 ; \mathrm{AGFI}=0.91 ; \mathrm{TLI}=0.96$; $\mathrm{CFI}=0.97 ; \mathrm{RMSEA}=0.069)$. The results of confirmatory factor analysis (CFA) are displayed in Table 1.

Table 1. CFA Results

\section{Constructs}

Utilitarian Value (C.R. $=0.80 ; \mathrm{AVE}=0.51 ; \alpha=0.80$ )

UV1 : The price of this smartphone brand is acceptable

UV2 : This smartphone brand is better value for money than what I would pay for the same brands

UV3 : I value the ease of using this smartphone brand

UV4 : I value the convenience of using this smartphone brand

Hedonic Value (C.R. $=0.87 ; \mathrm{AVE}=0.69 ; \alpha=0.87$ )

HV1 : Using this smartphone brand makes a good impression on other people $\quad 0.76$

HV2 : Using this smartphone brand gives me social approval 0.93

HV3 : Using this smartphone brand helps me to feel accepted by others $\quad 0.80$

Brand Affect (C.R. $=0.88 ; \mathrm{AVE}=0.71 ; \alpha=0.87$ )

BA1 : This brand gives me pleasure

BA2 : This brand makes me happy

BA3 : I feel good when I use this brand

Brand Trust (C.R. $=0.94 ; \mathrm{AVE}=0.81 ; \alpha=0.94$ )

BT1 : I trust this brand

BT2 : This brand is safe

\section{Model Fit Statistics}

Chi-square $(\chi 2)=277.063 \quad$ Df $=70 \quad \chi 2 / \mathrm{df}=3.96 \quad$ GFI $=0.94 \quad$ AGFI $=0.91$
TLI $=0.96$
CFI $=0.97 \quad$ RMSEA $=0.069$

Confirmatory factor loadings ranged from 0.42 and 0.87 for utilitarian value, 0.76 and 0.93 for hedonic value, 0.74 and 0.86 for brand affect, and 0.86 and 0.93 for brand trust. Composite reliabilities for the measurement scales (utilitarian value, hedonic value, brand affect and brand trust) ranged from 0.80 and 0.94. Average variance extracted (AVE) coefficents for the measurement scales ranged from 0.51 and 0.81 . Since both the model fit 


\section{Macrothink}

Journal of Management Research

ISSN 1941-899X

2014, Vol. 6, No. 2

statistics and factor loadings of all constructs were significant and acceptable, convergent validity was ensured.

The analysis of discriminant validity was executed to determine whether the constructs in the measurement model were different from each other. Discriminant validity was calculated by using Chi-square differences between the Model 1, where correlations fixed at 1, and the Model 2, where correlations were free (Bagozzi et al, 1991).

The results of discriminant validity analysis are given in Table 2 .

Table 2. Result of Discriminant Validity Analysis

\begin{tabular}{lll}
\hline Models & Chi-square $(\chi \mathbf{2})$ & Degree of freedom (df) \\
\hline Model 1 (Correlations fixed at 1) & 491.439 & 76 \\
Model 2 (Correlations free) & 277.063 & 70 \\
$\Delta \chi 2$ & 214.376 & \\
$\Delta$ df & & 6 \\
\hline
\end{tabular}

Discriminant validity was ensured whether the chi-square value of the unconstrained (free) model was significantly lower than the fixed model. According to $\chi^{2}$ distribution table, the critical value of 6 degrees of freedom is 12.591 . Therefore, the critical value $(\chi 2(6)>12.591)$ indicates that discriminant validity was upheld. Correlations among the constructs is shown in Table 3.

Table 3. Constructs Intercorrelations

\begin{tabular}{lllll}
\hline Constructs & 1 & 2 & 3 & 4 \\
\hline 1- Utilitarian Value & 1.00 & & & \\
2- Hedonic Value & 0.41 & 1.00 & & \\
3- Brand Affect & 0.64 & 0.47 & 1.00 & \\
4- Brand Trust & 0.69 & 0.31 & 0.83 & 1.00 \\
\hline
\end{tabular}

According to Table 3, correlation values between the constructs in the model ranged from 0.31 and 0.83 .

\subsection{Structural Model}

The structural analysis was employed using maximum likelihood estimate method. The structural model is presented in Figure 2. 


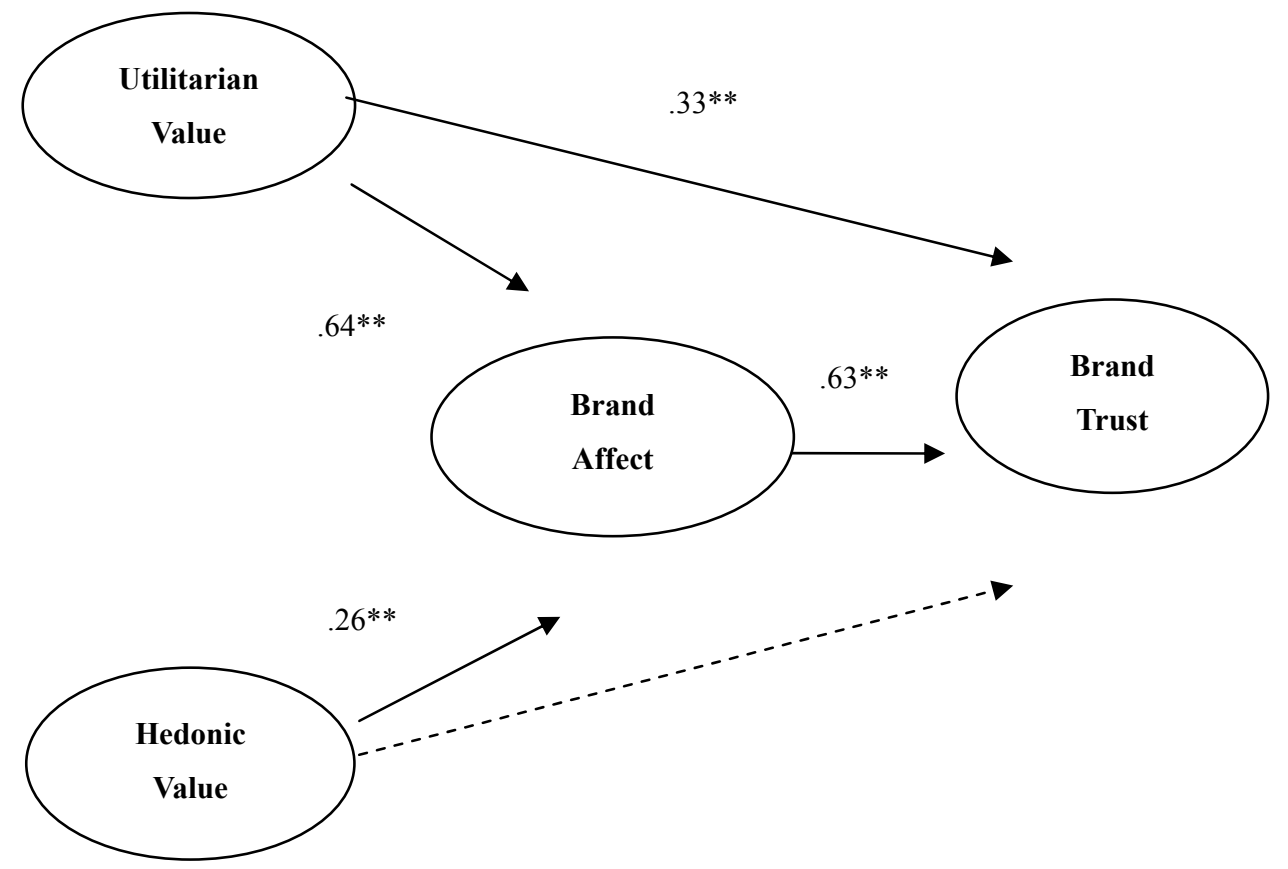

Figure 2. Structural model

Note. ${ }^{* *} \mathrm{p}<.001$

The results of structural equation modeling are shown in Table 4. Overall, the fit statistics provided an adequate model fit (Chi-square $\left(\chi^{2}\right)=330.374, \mathrm{df}=70, \chi 2 / \mathrm{df}=4.72, \mathrm{GFI}=0.94$, AGFI $=0.90$, TLI $=0.95$, CFI $=0.96$, RMSEA $=0.077)$. In view of squared multiple correlations, the degree of variance explained by utilitarian and hedonic values was 0.48 and the degree of variance explained for brand trust by three antecedents (utilitarian value, hedonic value and brand affect) was 0.74 . The results of hypotheses testing are also indicated in Table 4.

Table 4. Results of hypotheses testing

\begin{tabular}{lllllll}
\hline Hypothesized Path & & & Coefficent & t-Value & Sig. & Results \\
\hline $\mathrm{H} 1:$ Utilitarian Value & $\longrightarrow$ & Brand Affect & 0.64 & 12.604 & $* * *$ & Supported \\
\hline $\mathrm{H} 2:$ Hedonic Value & $\longrightarrow$ & Brand Affect & 0.26 & 6.992 & $* * *$ & Supported \\
\hline $\mathrm{H} 3:$ Utilitarian Value & $\longrightarrow$ & Brand Trust & 0.33 & 6.996 & $* * *$ & Supported \\
\hline $\mathrm{H} 4:$ Hedonic Value & $\longrightarrow$ & Brand Trust & -0.11 & -3.639 & $* * *$ & Rejected \\
\hline $\mathrm{H} 5:$ Brand Affect & $\longrightarrow$ & Brand Trust & 0.63 & 13.400 & $* * *$ & Supported \\
\hline $\begin{array}{l}\mathrm{R}^{2}(\text { Brand affect })=0.48 ; \\
\text { Notes: } * * *\end{array}<\mathrm{R}^{2}$ (Brand trust) $=0.74$ & & & &
\end{tabular}

Model Fit Statistics

Chi-square $(\chi 2)=330.374$

Degrees of freedom $(\mathrm{Df})=70$

$\chi 2 / \mathrm{df}=4.72$

$\mathrm{GFI}=$ 0.94

AGFI $=0.90 \quad$ TLI $=0.95 \quad$ CFI $=0.96 \quad$ RMSEA $=0.077$ 
As shown in Table 4, utilitarian and hedonic values were found to have significant relationships with brand affect, supporting $\mathrm{H} 1(\mathrm{t}=12.604 ; \mathrm{p}<.001)$ and $\mathrm{H} 2(\mathrm{t}=6.992 ; \mathrm{p}$ $<.001)$. But the impact of utilitarian value is greater than the effect of hedonic value (utilitarian value: $\beta=.64$, hedonic value: $\beta=.26$ ). While utilitarian value was positively related to brand trust $(\beta=.33 ; \mathrm{t}=6.996 ; \mathrm{p}<.001)$, hedonic value was found to have no significant impact on brand trust $(\beta=-.11 ; \mathrm{t}=-3.639 ; \mathrm{p}<.001)$. Therefore, $\mathrm{H} 3$ was supported and $\mathrm{H} 4$ was rejected. The linkage between brand affect and brand trust was significant ( $\beta$ $=.63 ; \mathrm{t}=13.400 ; \mathrm{p}<.001$ ), supporting H5. The findings of the hypotheses testing revealed that smartphone consumers' utilitarian value and brand affect significantly enhance their brand trust.

\section{Conclusion, Discussion and Implications}

The aim of this study was to examine the relationships among utilitarian and hedonic values, brand affect and brand trust in the smart phone industry. A research model was developed to test empirically the relationships among these constructs. The proposed hypotheses were then tested via the structural equation modeling. The utilitarian value and hedonic value were predictor variables and brand affect and brand trust were criterion variables in the analysis. As a result of the structural analysis, it is possible to state that the suggested model is able to significantly explain the brand trust of smartphone users $\left(\mathrm{R}^{2}=0.74\right)$.

The empirical findings revealed that utilitarian and hedonic values were found to significantly influence brand affect. This finding coincides with the results of Matzler et al. (2006b) in which they found significant and positive relationship between hedonic value and brand affect. It was expected that brand affect would be influenced much more than hedonic value; however, the current study indicated that the effect of utilitarian value (coefficient $U V=0.64$; coefficient $\mathrm{HV}=0.26$ ) was greater.

Utilitarian value comes into prominence, especially because smartphones possess many social and business facilities. Most of the processes that are carried out with computers can now be done with smartphones and users can access information easily, wherever and whenever they like. In the future, it is foreseen that the commitment to smartphones may undergo an important change in favor of the utilitarian value through the development and diversification of the functional properties of smartphones.

The increase in the functional efficiency of smartphones changes the perspective of users for the brand. Users' brand trust in the smartphone develops positively, as it is easy-to-use and the transactions conducted on the smartphones are fast, effective, and successful. The findings of the current research showed that the utilitarian value has a significant and positive effect on brand trust. However, it was also observed that hedonic value would not create a significant difference in the respondents' formation of trust for the smartphone brands they use. This result showed parallelism with the findings of Hanzaee \& Andervazh (2012), in which it was demonstrated that utilitarian and hedonic values affected brand trust directly and positively. In this regard, it can be stated that the consumers of this research considered only the functional utilities of the product when forming trust for smartphone brands. 
It is assumed that the previous emotional bond of users for the brand increases the brand trust. Similarly, it can be seen that negative prejudice creates a negative effect in the context of trust. The current study revealed that brand affect positively influences brand trust (coefficient $\mathrm{BA}=0.63)$. Furthermore, a very high level of correlation $(0.83)$ occured between brand affect and brand trust. In this regard, it can be expressed that this result is parallel to the findings of Chaudhuri \& Holbrook (2001) and Halim (2006).

Smartphones are expected to continue to live in users' pockets with their various functional characteristics and diverse visual richness as a result of the daily increase in technological change and development. The number of smartphone users increases every single day and an important target group is formed for the manufacturer firms. Therefore, the manufacturers in the industry aim to have a corner on the market by winning the approval and trust of consumers through the R\&D and innovations they carried out. On the other hand, the presence of an immense target group attracts other firms and urges them to integrate within this structure. Firms attempt to present their goods and services according to the user preferences via various software, in-app advertisements, and applications. This provides the smartphone users with an opportunity to access many goods and services easily and quickly. Thus, the commitment to these devices increases and the users care to opt for the right product regarding effective usage.

\section{Limitations and Directions for Further Studies}

The most important limitation of the research is the acquisition of the data by an online survey. The sample group consisted of only volunteers that agreed to participate in the online survey, and therefore, it does not seem possible to make a generalization about all smartphone users. Moreover, it is unknown under what conditions the participants completed the survey, and therefore, the reliability of the answers may be in question. Additionally, cross-sectional data collection caused negligence of changing consumer perceptions towards smartphone brands, which can be considered another limitation of the research.

Following this study, some suggestions may be offered for future studies. The research was conducted solely on smartphone users in Turkey. In future studies, it is possible to conduct comparative studies in which other technological products are included in the research. Moreover, the research model might be tested by conducting intercultural research among smartphone users in various countries.

The relationships between the structures within the research model were evaluated within the context of cross-sectional research design. Longitutinal studies may be beneficial in terms of the relationships among the constructs over time. Additionally, proportion of variance explained in brand trust can be enhanced by developing alternative models regarding the other determinants of brand trust. Moreover, some moderator variables can be added to the current model and their effect can be analyzed.

\section{References}

Anderson, J. C., \& Gerbing, D.W. (1988). Structural equation modeling in practice: A review and recommended two step aproach. Psychological Bulletin, 103(3), 411-423. 
http://dx.doi.org/10.1037/0033-2909.103.3.411

Anuwichhanont, J. (2011). The impact of price perception on customer loyalty in the airline context. Journal of Business\& Economics Research, 9(9), 37-49.

Babin, B., Darden, W., \& Griffin, M. (1994). Work and/or fun: measuring hedonic and utilitarian shopping value. Journal of Consumer Research, 20(4), 644-656, http://dx.doi.org/10.1086/209376

Bagozzi, R. P., Li, Y., \& Philips, L. W. (1991). Assessing construct validity in organizational research. Administrative Science Quarterly, 36(3), 421-458. http://dx.doi.org/10.2307/2393203

Batra, R., \& Ahtola, O.T. (1990). Measuring the hedonic and utilitarian sources of consumer attitudes. Marketing Letters, 2(2), 159-170. http://dx.doi.org/10.1007/BF00436035

Carpenter, J.M., Moore. M., \& Fairhurst, A.E. (2005). Consumer shopping value for retail brands. Journal of Fashion Marketing and Management, 9(1), 43-53. http://dx.doi.org/10.1108/13612020510586398

Chaudhuri, A., \& Holbrook, M. B. (2001). The chain of effects from brand trust and brand affect to brand performance: The role of brand loyalty. Journal of Marketing, 65(2), 81-93. http://dx.doi.org/10.1509/jmkg.65.2.81.18255

Childers,T.L., Carr, C.L., Peck, J., \& Carson, S. (2001). Hedonic and utilitarian motivations for online retail shopping behavior. Journal of Retailing, 77, 511-535. http://dx.doi.org/10.1016/S0022-4359(01)00056-2

Dhar, R., \& Wertenbroch. K. (2000). Consumer choice between hedonic and utilitarian goods. Journal of Marketing Research, 37, 60-71. http://dx.doi.org/10.1509/jmkr.37.1.60.18718

Dodds, W. B., \& Monroe, K.B. (1985). The effect of brand and price information on subjective product evaluations. Advances in Consumer Research, 12, 85-90.

Duman, T., \& Mattila, A.S. (2005). The role of affective factors on perceived cruise vacation value. Tourism Management, 26, 311-323. http://dx.doi.org/10.1016/j.tourman.2003.11.014

Erevelles, S. (1998). The role of affect in marketing. Journal of Business Research, 42, 199-215. http://dx.doi.org/10.1016/S0148-2963(97)00118-5

Gao, T., Rohm, A.J., Sultan, F., \& Huang, S. (2012). Antecedents of consumer attitudes toward mobile marketing: a comparative study of youth markets in the United States and China. Thunderbird International Business Review, 54(2), 211-224. http://dx.doi.org/10.1002/tie.21452

Geçti, F., \& Zengin, H. (2013). The relationship between brand trust, brand affect, attitudinal loyalty and behavioral loyalty: a field study towards sports shoe consumers in Turkey. International Journal of Marketing Studies, 5(2), 111-119. http://dx.doi.org/10.5539/ijms.v5n2p111 
GFK, (2013). Q4 2013: Temax shows growth for Turkish technical consumer goods market. Retrived February 28, 2014, from http://www.gfk.com/temax/turkey-and-middle-east/Pages/turkey.aspx

Gommans, M., Krishnan, K.S., \& Katrin B. Scheffold (2001). From brand loyalty to e-loyalty: a conceptual framework. Journal of Economic and Social Research, 3(1), 43-58.

Ha, H.Y. (2004). Factors influencing consumer perceptions of brand trust online. Journal of $\begin{array}{llll}\text { Product } \quad \& \quad \text { Brand } \quad \text { Management, } & 13(5),\end{array}$ http://dx.doi.org/10.1108/10610420410554412

Halim, R. E. (2006). The effect of the relationship of brand trust and brand affect on brand performance: An analysis from brand loyalty perspective- A case of coffee instant product in Indonesia. Retrieved from http://ssrn.com/abstract=925169

Hanzaee, K. H., \& Andervazh, L. (2012). An analysis of some moderating variables on the value, brand trust and brand loyalty chain. Research Journal Applied Sciences, Engineering and Technology, 4(10), 1403-1413.

Harris, L. C., \& Goode, M. M. H. (2004). The four levels of loyalty and the pivatal role of trust: a study of online service dynamics. Journal of Retailing, 80, 139-158. http://dx.doi.org/10.1016/j.jretai.2004.04.002

Hirschman, E. C., \& Holbrook, M. (1982). Hedonic consumption: emerging concepts, methods and propositions. Journal of Marketing, 46(3), 92-101, http://dx.doi.org/10.2307/1251707

Hopkinson, G.C., \& Pujari, D. (1999). A factor analytic study of the sources of meaning in hedonic consumption. European Journal of Marketing, 33(3/4), 273-294. http://dx.doi.org/10.1108/03090569910253053

Ibanez, V. A., Hartmann, P., \& Calvo, P. Z. (2006). Antecedents of customer loyalty in residential energy markets: service quality, satisfaction, trust and switching costs. The Service Industries Journal, 26(6), 633-650. http://dx.doi.org/10.1080/02642060600850717

IDC, (2013). Worldwide smartphone shipments top one billion units for the first time, according to IDC (International Data Corporation). Retrived February 27, 2014, from https://www.idc.com/getdoc.jsp?containerId=prUS24645514

Jahangir, N., Parvez, N., Bhattacharjee, D., \& Ahamed, K. K. (2009). The relationship between brand affect, brand quality, and customers' brand extension attitude: exploring the mediating role of customer loyalty. The Cambodian Management Journal, 1(1), 20-34.

Jones, M.A., Reynolds, K.E., \& Arnold, M.J. (2006). Hedonic and utilitarian shopping value: investigating differential effects on retail outcomes. Journal of Business Research, 59, 974-981. http://dx.doi.org/10.1016/j.jbusres.2006.03.006

Kabadayı, E.T., \& Alan, A.K. (2012). Brand trust and brand affect: their strategic importance on brand loyalty. Journal of Global Strategic Management, 6(1), 81-89 
Liu, C. T., Guo, Y. M., \& Le, C. H. (2011). The effects of relationship quality and switching barriers on customer loyalty. International Journal of Information Management, 31, 71-79. http://dx.doi.org/10.1016/j.ijinfomgt.2010.05.008

Matzler, K., Krauter, S. G., \& Bidmon, S. (2006a). The value - brand brust - brand loyalty chain: an analysis of some moderating variables. Innovative Marketing, 2(2), 76-88

Matzler, K., Krauter, S. G., \& Bidmon, S. (2006b). Individual determinants of brand affect: the role of the personality traits of extraversion and openness to experience. Journal of $\begin{array}{lllll}\text { Product } \quad \text { \& } \quad \text { Brand } & \text { 427-434. }\end{array}$ http://dx.doi.org/10.1108/10610420610712801

Matzler, K., Krauter, S. G., \& Bidmon, S. (2008). Risk aversion and brand loyalty: The mediating role of brand trust and brand affect. Journal of Product \& Brand Management, 17(3), 154-162. http://dx.doi.org/10.1108/10610420810875070

Moorman, C., Zaltman, G., \& Deshpande, R. (1992), Relationships between providers and users of market research: the dynamics of trust within and between organizations. Journal of Marketing Research, 29(3), 314-328. http://dx.doi.org/10.2307/3172742

Morgan, R. M., \& Hunt, S. D. (1994), The commitment-trust theory of relationship marketing. Journal of Marketing, 58(3), 20-38. http://dx.doi.org/10.2307/1252308

Ok, C., Choi, Y. G., \& Hyun, S. S. (2011). Roles of brand value perceptions in the development of brand credibility and brand prestige. ICHRIE Conference Refereed Track, University of Massachusetts, 1-8.

Overby, J.W., \& Lee, E.J. (2006). The effects of utilitarian and hedonic online shopping value on consumer preference and intentions. Journal of Business Research, 59, 1160-1166. http://dx.doi.org/10.1016/j.jbusres.2006.03.008

Pihlström, M. (2007). Committed to content provider or mobile channel? determinants of continuous mobile multimedia service use. Journal of Information Technology Theory and Application, 9(1), 1-23.

Pura, M. (2005). Linking perceived value and loyalty in location-based mobile services. Managing Service Quality, 15(6), 509-538. http://dx.doi.org/10.1108/09604520510634005

Ryu, K., Han, H., \& Jang, S.S. (2010). Relationships among hedonic and utilitarian values, satisfaction and behavioral intentions in the fast-casual restaurant industry, International Journal of Contemporary Hospitality Management, 22(3), 416-432. http://dx.doi.org/10.1108/09596111011035981

Sung, Y., \& Kim, J. (2008). Effects of brand personality on brand trust and brand affect. Psychology \& Marketing, 27(7), 639-661. http://dx.doi.org/10.1002/mar.20349

Sweeney, J.C., Soutar, G.N., \& Johnson, L.W. (1997). Retail service quality and perceived value-a comparison of two models. Journal of Retailing and Consumer Services, 4(1), 39-48.

Taylor, S. A., Celuch, K., \& Goodwin, S. (2004). The importance of brand equity to customer 


\section{Macrothink}

Journal of Management Research

ISSN 1941-899X 2014, Vol. 6, No. 2

loyalty. Journal of Product \& Brand Management, 13(4), 217-227. http://dx.doi.org/10.1108/10610420410546934

Ting, D.H., Lim, S.F., Patanmacia, T.S., Low, C.G., \& Ker, G.C. (2011). Dependency on smartphone and the impact on purchase behaviour, Young Consumers, 12(3), 193-203. http://dx.doi.org/10.1108/17473611111163250

Woodruff, R. B. (1997). Customer value: the next source of competitive advantage. Journal of the Academy of Marketing Science, 25(2), 139-153. http://dx.doi.org/10.1007/BF02894350

Yang, Z., \& Peterson, R.T. (2004). Customer perceived value, satisfaction, and loyalty: the role of switching costs. Psychology \& Marketing, 21(10), 799-822. http://dx.doi.org/10.1002/mar.20030

Zeithaml, V.A. (1988). Consumer perceptions of price, quality and value: a means-end model and synthesis of evidence. Journal of Marketing, 52, 2-22. http://dx.doi.org/10.2307/1251446 